\title{
International Society of Invasive Cardiology in Congenital Heart Disease
}

For some years, a number of paediatric interventional cardiologists have discussed the possibility of developing a 'Society' dedicated to the needs of individuals involved in catheterization studies for patients with congenital heart lesions. From these discussions, evolved an ad hoc committee of interested individuals from around the world who participated in the development of goals and objectives for such a society. A constitution was developed and Dr. Shakeel A. Qureshi and Dr Lee Benson are pleased to announce the formation of the International Society for Invasive Cardiology in Congenital Heart Disease, and invite applications for membership.

The purposes of this Society are to promote the application of invasive techniques in cardiology as applied to infants, children, adolescents and adults with congenital heart disease throughout the world, promote and distribute study data pertaining to these techniques, help those engaged in this work and promote communication, education, research and co-operation between workers in this and related fields.

The first meeting will coincide with the World Congress of Pediatric Cardiology in May 2001 in Toronto.

Many initiatives have been considered and discussed including a webpage (www.ISICCHD. org), a venue for publications, an annual meeting and symposium.

The Constitution and a Membership application form follow.

\author{
Lee Benson, MD, FRCPC, FACC, FSCAI \\ Professor of Paediatrics (Cardiology) \\ Director, Variety Club Cardiac \\ Catheterization Laboratories \\ The Hospital for Sick Children \\ 555 University Avenue \\ Toronto, OntarioUK \\ Canada M5G 1X8
}

Phone: 0014168136141

Fax: 0014168137547

\author{
Dr Shakeel A Qureshi, MB, ChB, FRCP \\ Consultant Paediatric Cardiologist \\ Director, Cardiac Catheterisation Laboratory \\ Guy's Hospital \\ St Thomas Street \\ London SE1 9RT \\ Phone: $0044(0) 2079558772$ \\ Fax: $0044(0) 2079554614$ \\ E-mail: Shakeel.Qureshi@gstt.sthames.nhs.uk
}

Constitution of the International Society of Invasive Cardiology in Congenital Heart

Disease

Article I - NAME

Section 1

The name of this organization shall be called 'The International Society of Invasive Cardiology in Congenital Heart Disease'.

\section{Article II - PURPOSE}

Section 1

This is a non-profit making organization. The purposes of this organization are to:

1. Promote the study of the application of invasive techniques in cardiology, as applied in infants, children, adolescents and adults with congenital heart disease, throughout the world;

2. To promote and distribute study data (i.e., multinational registries, clinical impact assessments) pertaining to these techniques and their application;

3. To help those engaged in this work; and

4. To promote communication, education, research and co-operation between workers in this and related fields. 


\section{Article III - MEMBERSHIP}

\section{Section 1}

The society shall consist of Ordinary, Associate and Corresponding Members.

\section{Section 2}

Ordinary membership: shall be given to medical practitioners (pediatric or adult cardiologists, interventional radiologists) of consultant or equivalent level, and others, whose primary interest is in the practice or research of invasive cardiology in congenital heart disorders.

\section{Section 3}

A member may cease to be an ordinary member at any time, and may choose to become a Corresponding Member.

\section{Section 4}

Associate membership: will be given to individuals engaged in any aspect of training in invasive cardiology in congenital heart disorders. Such members will be ineligible to vote or hold office.

\section{Section 5}

Corresponding membership: may be given to recognized physicians, surgeons, or others, who have a clear and continuing link with invasive cardiology in children's heart disease.

\section{Section 6}

Corresponding members will not be eligible to vote or hold office.

\section{Section 7}

Original membership shall be available to all qualified individuals and presented to the first Annual General Meeting. Subsequent applications for any category of membership shall be considered by the Council and ratified at the Annual General Meeting. Such applications shall be proposed and seconded by 2 ordinary members.

\section{Article IV - SUBSCRIPTIONS}

\section{Section 1}

The annual subscription and the due date shall be fixed by the Council. Failure to pay within 1 year of the due date shall be considered equivalent to resignation of membership.

\section{Section 2}

The annual membership subscription, payable by ordinary members, shall be $\$ 50.00$ dollars (USD), subject to changes, and shall be payable on the First of January.

\section{Article V - OFFICERS}

\section{Section 1}

The officers of this organization shall be President, Vice President (President-Elect), Secretary, Treasurer, and 6 elected Council Members. The elected members shall, as far as possible, reflect the composition and various interests of the Association. The officers shall have been voting members of this organization for at least 1 year prior to their election.

\section{Section 2}

All officers will be in post for 2 years and will offer themselves to re-election after 2 years.

\section{Section 3}

The President automatically stands down after 2 years and is replaced by the Vice-President (President-Elect). However, the President shall be eligible for a non-executive position on the Council 2 years after ceasing to be the President.

The Secretary and Treasurer shall be eligible for re-election after 2 years.

Ordinary Council Members shall be elected for 2 years.

No officer shall serve on the Council for more than 2 consecutive 2-yearly terms (maximum of 4 years), but will be eligible for re-election 2 years after ceasing to hold office.

\section{Section 4}

The elected officers shall form the Executive Council for the organization.

\section{Article VI - AMENDMENTS}

\section{Section 1}

The constitution may be amended by a $2 / 3$ vote of the members present at the Annual General Meeting, providing the amendment has been proposed in writing and recorded at the last Annual General Meeting. 
By-laws of the International Society of Invasive Cardiology in Congenital Heart Disease

\section{Article I - MEETINGS}

Section 1

The Annual General Meeting shall be held in conjunction with a major international cardiology meeting, as decided upon by the Council. This will consist of a scientific and business meeting. The program and agenda shall be organized by the Council and will complement the program of presentation of papers presented at the sister meeting.

\section{Section 2}

Additional meetings of the Association shall be arranged at the discretion of the Council and will similarly rotate around the world. The topics will be selected at the discretion of the Council, who will take into account suggestions from the members. A local organization shall be nominated for this second meeting, but the overall organization shall remain the responsibility of the Council.

\section{Section 3}

A Quorum shall consist of not less than 20 members.

\section{Article II - FISCAL YEAR}

Section 1

The fiscal year shall correspond with the term of office of the officers.

\section{Section 2}

Newly elected officers shall assume office at the close of the Annual General Meeting and hold office for 2 years or until a duly elected successor takes office.

\section{Article III - ELECTION OF OFFICERS \\ Section 1}

Until such time as election of the Council takes place, a Steering Committee shall act in the capacity of the Council. The Steering Committee shall present a list of candidates for elections, but nominations will also be accepted from the membership. Nominations and elections will be conducted by a postal ballot and the results will be notified at the Annual General Meeting. A straight majority will be sufficient for election.
Section 2

The nominations should take place in January and the elections in the following March.

\section{Article IV - DUTIES OF OFFICERS}

\section{Section 1}

The President shall preside at all the meetings, have general supervisory powers over the organization, see that the officers perform their duties, and enforce the By-Laws. He will appoint the chairman of all the sub-committees. He will cast the deciding vote when there is a tie in the balloting.

\section{Section 2}

The Vice-President (President-Elect) shall preside in the absence of the President and in case of death, sickness, resignation, disqualification, refusal, or neglect of the President, to discharge the duties of his office. The Vice-President (PresidentElect) shall then perform all duties incumbent upon the President for the remainder of the term of office.

\section{Section 3}

The Secretary shall keep a record of the proceedings of the organization and prepare a roll of members. The Secretary will call the meeting in the absence of the President and Vice-President (President-Elect). The Secretary shall be in charge of scheduling and printing the meeting program for the year.

\section{Section 4}

The Treasurer shall receive all monies of the organization, pay bills, disburse funds as directed, and have all accounts receipt upon payment of the same. The Treasurer shall be charged with the collection of subscriptions. All disbursements shall be by cheque and require the signature of the Treasurer or, in his absence, the Secretary. The Treasurer shall give a financial report at the Annual General Meeting.

\section{Section 5}

In case of death, sickness, or resignation of the Vice-President (President-Elect) or the Secretary, or the Treasurer, the Council will present a list of candidates to the membership for election. 


\section{Article V - SUBSCRIPTIONS}

Section 1

Subscriptions shall be collected annually for each ordinary member. Associate and Corresponding members shall be exempt from paying subscriptions. The Council shall propose the subscription and this will need ratification at the Annual General Meeting.

\section{Article VI - AMENDMENTS}

\section{Section 1}

These By-Laws may be amended by a two-thirds vote of the members present at the Annual General Meeting, providing the amendment has been proposed in writing and recorded at the last Annual General Meeting.

\section{Article VII - CONVENING OF SUB- COMMITTEES}

\section{Section 1}

The Council shall have the right to convene subcommittees as it deems necessary.

\section{Article VIII - NON-PROFIT STATUS AND DISSOLUTION}

Section 1

No part of the net earnings of the organization shall inure to the benefit of any individual or member. Where appropriate, the Executive Council may determine to compensate reasonably any officer of the organization in accordance with and commensurate with the labour, services, or other endeavors performed by such persons.

\section{Section 2}

In the event of the dissolution of this organization, or in the event it shall cease to exist for the stated purposes, all the property and assets shall be distributed to an organization or agency of similar nature and charitable and non-profit status. This allocation shall be decided by the Council at the time of dissolution. Under no circumstances shall any of the property or assets of this organization during the existence and/or upon the dissolution thereof go and be distributed to any officer or member of the organization.

\section{International Society of Invasive Cardiology in} Congenital Heart Disease

Membership application for the international society for invasive cardiology in congenital disease

Name:

Work address:

\section{Country:}

Telephone no:

Fax no:

E-mail:

Subspecialty:

Home address:

Preferred contact address:

Membership dues are $\$ 50.00$ US per year.

Please make cheques payable to: The Research Institute, The Hospital For Sick Children, 555 University Avenue, Toronto, Ontario, M5G 1X8, Canada

A receipt will be forwarded. 